Relations industrielles

Industrial Relations

\title{
Sociologie des conflits du travail, par Jean-Daniel Reynaud, Paris, Presses Universitaires de France, 1982, 127 pp.
}

\section{Alexander J. Matejko}

Volume 38, numéro 3, 1983

URI : https://id.erudit.org/iderudit/029389ar

DOI : https://doi.org/10.7202/029389ar

Aller au sommaire du numéro

Éditeur(s)

Département des relations industrielles de l'Université Laval

ISSN

0034-379X (imprimé)

1703-8138 (numérique)

Découvrir la revue

Citer ce compte rendu

Matejko, A. (1983). Compte rendu de [Sociologie des conflits du travail, par Jean-Daniel Reynaud, Paris, Presses Universitaires de France, 1982, 127 pp.] Relations industrielles / Industrial Relations, 38(3), 681-682.

https://doi.org/10.7202/029389ar

Tous droits réservés (C) Département des relations industrielles de l'Université Laval, 1983
Ce document est protégé par la loi sur le droit d'auteur. L'utilisation des services d'Érudit (y compris la reproduction) est assujettie à sa politique d'utilisation que vous pouvez consulter en ligne.

https://apropos.erudit.org/fr/usagers/politique-dutilisation/ 
Sociologie des conflits du travail, par JeanDaniel Reynaud, Paris, Presses universitaires de France, 1982, 127 pp.

In the confrontation between organized employees and employers there are several factors that count, and J.D. Reynaud in his short book tries to cover at least the most important ones. How many people will joint a collective action, who will sponsor it, how dedicated people will be to their common cause, differ widely in various economic branches, occupations enterprises and whole societies. The work stoppages are in France treated by law much more tolerantly than in the Anglo-Saxon countries or in West Germany. This does not necessarily mean that France suffers much because of strikes: for several years, the time lost on strikes has not grown above 2.5 per cent of total absenteeism and 2 per thousand of the whole yearly work time. France has much more strikes than West Germany, Austria, Holland and Netherland but much less than the U.S., the U.K., Canada and Italy. The strikes in France have a local character and last for short time because they give an outlet to the dissatisfaction of employees and do serve primarily, as this happens in several other countries, as a weapon of collective bargaining. The average strike in France mobilises no more than 200 employees and lasts from 3 to 5 days (p. 22). Skilled male manual workers in the year group 25 to 40 are the most common category on strike. However, with the changes of the labour force also other categories (women, unskilled workers, etc.) become more common among the strikers.

The author pays attention to the fact that blue collar workers in the developed market societies are far from being polarized as Marx predicted, and their appearance in the whole variety of roles (consumers, citizens, etc.) contributes to the pragmatic nature of labour conflicts (p. 117). The state takes a much more active role than before; the institutionalisation of labour conflicts makes a progress; the nature of authority is changing substantially. In France, under the socialist rule cosponsored by communists, the role of the state in regulating labour problems has become particularly sensitive. On one hand, the traditional high socio-economic inaqualities remain intact and the state is counscious not to aggrevate too much its mutual relations with the organized private entrepreneurs. On the other hand, the difficult economic situation of France makes necessary to introduce several unpopular measures oriented towards the deteriorating balance of payments.

Industrial peace not being obligatory for the French bargaining powers makes strikes difficult to predict, especially because very many among them arise at the local level. In France, various unions coexist with each other at the entreprise level and this additionally encourages them to be enough militant in order to make their members happy. The system of grievances is located externally and misses the advantages of those systems that are located within the entreprises. Strikes are just a vital part of continuous bargaining and under the circumstances signified by a divided trade unionism promoted by some militants quite often a semi-formal political intervention is needed in order to find a temporary solution. The power game between unions and employers that develops under such conditions is not necessarily explainable in the categories of different vested interests and rationalities based on them. Depending on changing circumstances also the demands change in order not only to achieve something specific but also improve the relative position versus the "adversary». The coalition of various interests may be quite shaky, particularly in the case of trade unions having a diversified membership; to achieve a satisfactory compromise may be a difficult thing.

The author pays a particular attention to the fact that private interests do not go easily together with the collective interests. It is quite often more convenient for an individual to leave to others the cost and the risk of taking an action but afterwards, when the latter succeeds, the individual participates anyway in all advantages. With the unions being bas- 
ed on a diversified membership, the traditional social pressures cease to act as efficiently as before and the unions have to look for other ways to make their members loyal. The socialisation of people into their trade unions is a difficult problem particularly in France where the workers easily switch from one union to another and the unions are in general too poor to offer their membership several attractive advantages. Depending on the mobilization potential of a given union there is more or less chance that others will follow; when there is not enough dedicated members, the strike becomes impossible; the collective advantages of a joint action may differ widely depending how much people gain out of this action. Unions differ in the general model followed by them and the suitability of it to the given circumstances plays a considerable role.

It is an interesting question whether modern trade unions, as they are described by the author, are really successful in the formulation of models suitable to the present day conditions. In France, the unions remain relatively weak and insecure even under the socialist government; many of their militant actions originate from insecurity and not from power; the politicisation of unions shows evidently that the traditional basis of their activities is not enough stable in order to act independently; several important categories of the working population remain beyond the scope of trade unionism; internal democracy within unions is either non existent or underdeveloped.

J.D. Reynauld treats the problem solving process related to strikes as a great occasion to change gradually the circumstances, make them move adequate to the growing expectations of involved partners. The authority relationships are being transformed in order to offer more power than before to the representation of the employees. The great social-political crisis in France of the late 1960s and the early 1970s has shown that the traditional central authority is in practice much less rooted than it was expected. The author is right emphasises that the phenomenon of strikes is just only a manifestation of some deeper trends and contradictions existing in the modern society.

Alexander J. MATEJKO

University of Alberta

\section{Managing Individual and Group Behavior} in Organizations, par Daniel C. Feldman et Hugh J. Arnold, McCrowill-Hill Series in Management, Toronto, 1983, 613 pp., ISBN 0-8359-3006-4

Ce n'est pas une tâche facile de donner une appréciation correcte d'un ouvrage lorsqu'après en avoir fait une première lecture rapide, on n'y retrouve rien de nouveau. C'est le sentiment que nous avons ici en abordant l'ouvrage substantiel de Feldman et Arnold qui s'inscrit dans la foulée d'une vingtaine de bons manuels de base en sciences du comportement appliquées aux organisations de travail. On sait que ce domaine traite des perceptions, des attitudes, des motivations, de la performance des individus et des groupes au sein des organisations. En s'en tenant à ce qui est essentiel et pertinent, les auteurs se sont donnés comme tâche de présenter clairement ce que nous savons actuellement sur le sujet et ils ont très bien réussi à le faire. En laissant de côté l'introduction et la conclusion, l'ouvrage se divise en six grandes parties: 1) l'intégration des individus aux organisations via la description des fonctions, le recrutement, la sélection et la socialisation des individus; 2) les problèmes de motivation, de satisfaction au travail et de rendement; 3) la restructuration du travail via l'élargissement des tâches et l'implantation de groupes semi-autonomes; 4) le leadership sous l'angle des traits de la personnalité ou bien sous l'angle des styles de leadership appropriés ou non aux diverses situations administratives; 5) les autres types d'influence via la prise de décision, la communication, l'appréciation de la performance; 6 ) les phénomènes de groupe où l'on examine les facteurs de conformisme ou de 